\title{
Advanced differentiation in trichoepithelioma and basal cell carcinoma investigated by immunohistochemistry against neurofilaments
}

\author{
Angel Fernandez-Flores
}

Service of Anatomic Pathology, Hospital El Bierzo and the Service of Cellular Pathology, Clinica Ponferrada, Ponferrada, Spain

\begin{abstract}
Basal cell carcinoma (BCC) and trichoepithelioma (TE) are sometimes diagnostic challenges for the pathologist in terms of their differential diagnosis. Although literature is quite rich in information about histologic and immunohistochemical clues to distinguish the differences between both, no single finding must be completely reliable. Moreover, some consider that $\mathrm{TE}$ is a better differentiated follicular tumour, while BCC represents a less developed stage in differentiation. For instance, the latter opinion is supported by the evidence of follicular papillae in TE. The formation of a perifollicular nerve plexus happens later than the formation of the follicular papillae in the development of a normal follicle. The study of the presence of the perifollicular nerve plexus in both tumours which could then provide us with evidence on the stage of differentiation of both tumours. 5 cases of TE and 10 cases of BCC were randomly selected from our archives and an immunohistochemical study for neurofilaments was performed in all the cases. We found a peritumoural nerve plexus in all the cases (TEs and BCCs). Since this plexus is a late sign of differentiation and since both types of neoplasias share it, we conclude that TE and BCC are both terminally differentiated neoplasms. The ability of BCC to infiltrate would have more to do with the acquisition by the tumour of such a property, rather than with a stage of indifferentiation.
\end{abstract}

Keywords: neurofilament, trichoepithelioma, basal cell carcinoma

\section{Introduction}

Distinguishing between trichoepithelioma (TE) and basal cell carcinoma (BCC) is sometimes a very difficult task. Literature is full of reports that offer diagnostic clues, but the fact that many of those clues are immunohistochemical [1-11], ultrastructural [12] or even molecular [13], gives the idea that the subject is far from being simple.

Although most agree that TE and BCC show follicular differentiation, some consider that both entities represent different stages of differentiation: TE would represent a more developed stage of differentiation. The fact that TE shows papillary mesenchymal bodies while BCC does not, would support that hypothesis.

In this study, we focussed our attention on the existence of a peritumoural nerve plexus. In the normal development of the hair follicle, a perifollicular nerve plexus develops after the follicular papilla

Correspondence: A. Fernandez-Flores, S. Patología Celular, Avenida Galicia 1, 24400 Ponferrada, Spain;

tel.: (+34987) 423732, fax.: (+34987) 429102,

e-mail: gpyauflowerlion@terra.es appears [14] (Fig. 1). This latter fact means that the evidence of the plexus is a finding indicative of later differentiation than the one that follicular papilla indicates. The evidence of such a plexus around TE and BCC, or its absence in any of those entities, might be then contributive in supporting or contradicting the hypothesis of TE as a better differentiated entity than BCC.

\section{Materials and methods}

We randomly selected $5 \mathrm{TE}$ and $10 \mathrm{BCC}$ from our archives and checked the slides in order to confirm the diagnosis. All the cases had been diagnosed with routine techniques $(\mathrm{H}+\mathrm{E})$, and classified according to the criteria that are described in the book of Lever's histopathology of the skin [15]. We also tested the existence of a peritumoural nerve plexus with an immunohistochemical study for neurofilaments (Dakocytomation mouse anti-human antibody against neurofilament protein, clone 2F11; code M0762) in all the cases.

\section{Results}

In all the cases, the original diagnosis was confirmed (5 TE and 10 BCC). All TE were conventional. Seven 

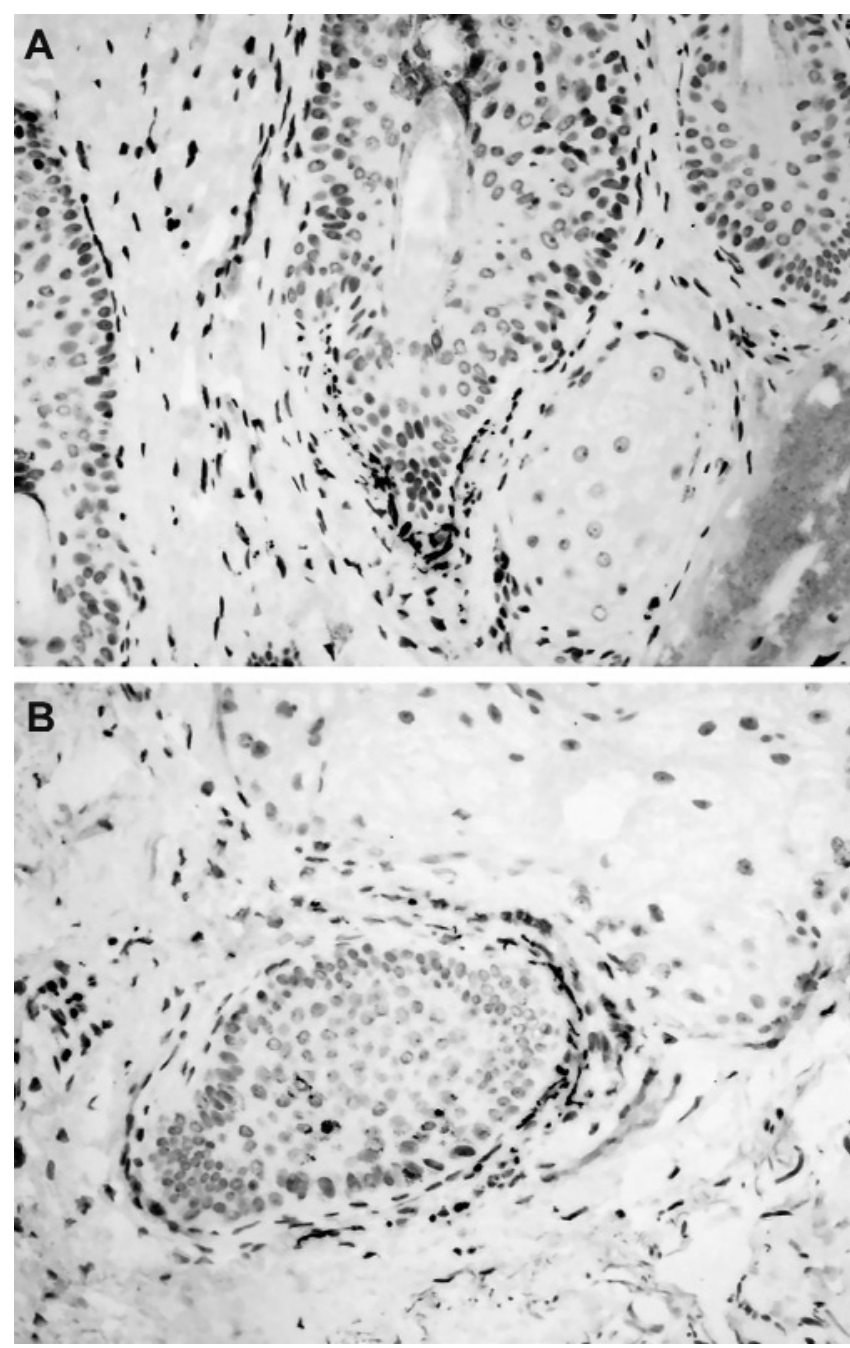

Fig. 1. Nerve plexus around a normal follicle. A. vertical section. B. transversal section (original magnification $\times 20$ ).

BCC belonged to the solid circumscribed variant; two of them were diagnosed as the solid infiltrative variant; one of them belonged to the morphea-like variant.

The details about the patients plus the location of the lesions are shown in Table 1. The immunostaining for neurofilaments showed a similar pattern in all the cases: a peritumoural nerve plexus was evident and was focally around tumoural islets, either of TE (Fig. 2) or of BCC (Fig. 3), mimicking the one evidenced in the normal follicle (Fig. 1). The plexus was either made of sparse fibres (Fig.3) or small groups of fibres (Fig. 1), and although its density slightly varied from case to case, the pattern was similar to the one observed around normal follicles.

\section{Discussion}

The distinction between basal cell carcinoma (BCC) and desmoplastic trichoepithelioma (TE) is not always easy. Literature is fully provided with many histologi-

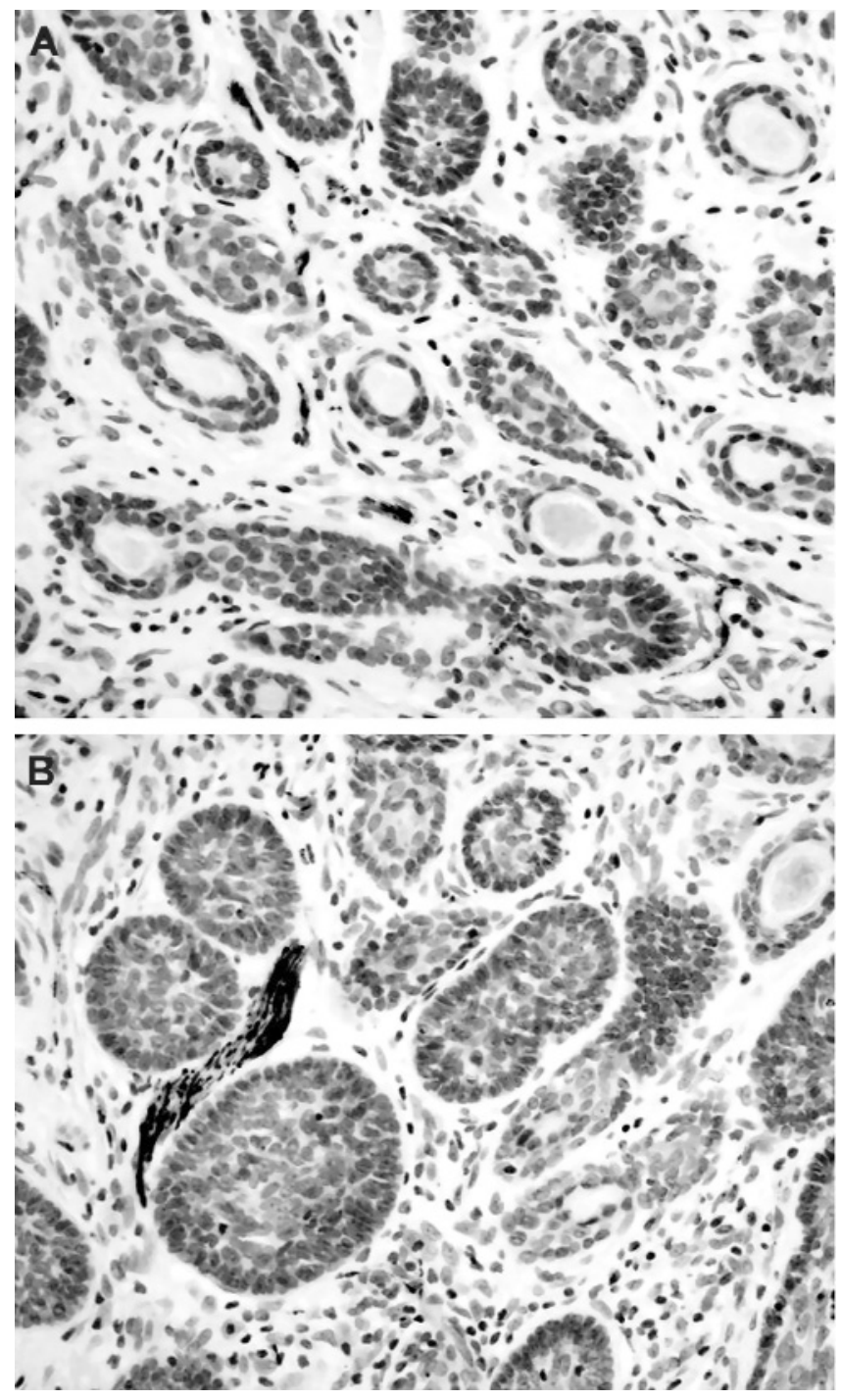

Fig. 2. Nerve plexus around two cases of trichoepithelioma. The fibres were scarce in some areas (A), while arranged in small groups in others $(\mathbf{B})$ (original magnification $\times 20$ ).

cal criteria in the differential diagnosis between both entities [16-20]. Nevertheless, the subject is far from being simple, taking into account the number of immunohistochemical studies [1-11], studies in molecular pathology [13], in immunofluorescence [21], or in ultrastructural pathology [12] that have focussed their attention on these different techniques for distinguishing both tumours from each other. The distinction is more important (although many times also very difficult) in small biopsies from delicate areas of the skin, such as the periocular tissues, owing to the different management of both tumours[22].

Many of the studies mentioned above have mainly focussed on the phenotype of the tumoural cells [2,3,5,6,9-11] including their proliferation rate [9]. Nevertheless, some other groups have also evaluated the expression of certain immunohistochemical mark- 


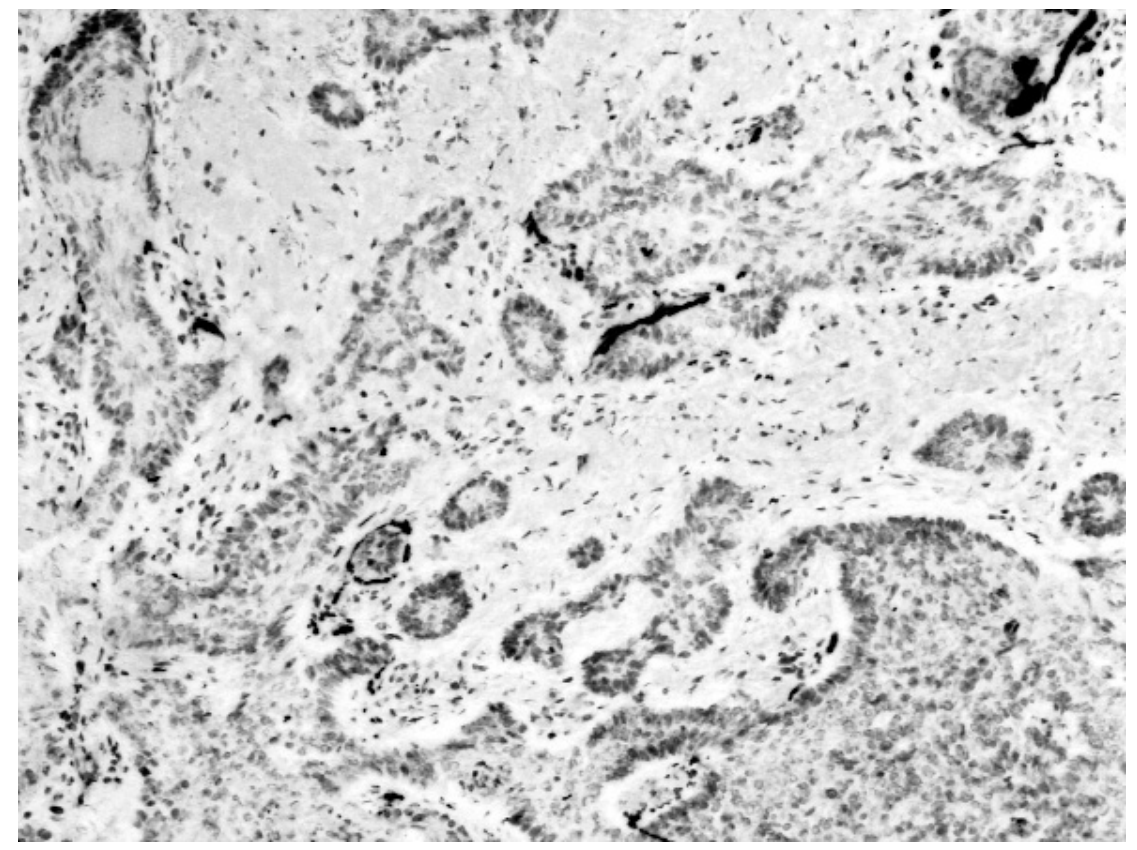

Fig. 3. Nerve plexus in a case of BCC, in which the fibres can be seen surrounding many of the tumour islets, with a spare distribution (original magnification $\times 10$ ).

Table 1. Cases in which the peritumoral plexus were investigated with immunohistochemistry.

\begin{tabular}{|c|c|c|c|c|}
\hline Case & Gender & $\mathrm{Agc}$ & lumor & Location \\
\hline 1 & Malc & 88 & $\mathrm{BCC}$, nodular & Right paranasal area \\
\hline 2 & l'emale & 80 & $\mathrm{BCC}$, infiltrating & Upper lip \\
\hline 3 & Malc & 74 & $\mathrm{BCC}$, nodular & Infra-auricular area \\
\hline 4 & Male & 80 & $\mathrm{BCC}$, nodular & Pre-auricular area \\
\hline 5 & Female & 78 & $\mathrm{BCC}$, nodular & I eft Nasogenian fold \\
\hline 6 & Male & 80 & $\mathrm{BCC}$, nodular & Face \\
\hline 7 & Male & 75 & $\mathrm{BCC}$, infiltrating & Right nasogenian fold \\
\hline 8 & Female & 90 & $\mathrm{BCC}$, nodular & I.eft nasogenian fold \\
\hline 9 & Malc & 77 & $\mathrm{BCC}$, morpheiphorm & Dorsal aspect of the nose \\
\hline 10 & Male & 74 & $\mathrm{BCC}$, nodular & Dorsal aspect of the nose \\
\hline 11 & l'cmalc & 45 & Trichospithclioma & l'orchead \\
\hline 12 & Male & 69 & Trichoepithelioma & Nose \\
\hline 13 & Female & 80 & Trichoepithelioma & I.eft parietal side of the head \\
\hline 14 & Male & 82 & Trichoepithelioma & Lower eyelid of the right eye \\
\hline 15 & Female & 69 & Trichoepithelioma & Back \\
\hline
\end{tabular}

ers in the tissues surrounding the tumoural cells, like the stroma $[1,3,4,11,21]$ or the basal membrane [21].

In our study, we focussed on a well known fact in normal histology, that nerve endings form a rich plexus around normal hair bulbs[23].

Some embryology studies have demonstrated that although some scattered nerve fibres appear before any morphological evidence of hair follicle development exists [24], a proper perifollicular nerve plexus appears ontologically after the development of the follicular papilla [14].

Many authors have remarked that TE and BCC probably have a common origin from pluripotential cells that develop towards hair structures [19,25-29]. According to some, both neoplasms would differ in their degree of differentiation, since TE would present a higher degree of differentiation, plus a more abundant peri-tumoural stroma [28]. One of the well recognized histological 
clues in the recognition of trichoepithelioma is the presence of papillary mesenchymal bodies [17]. The latter finding is only occasionally found in BCC [17]. The hair bulb formation appears to be even more exclusive, which seems to be a "privilege" of TE over BCC [17]. All these findings would agree with the argument that TE is a more differentiated expression of a follicular tumour. Nevertheless, the finding of a peritumoural nerve plexus in TE as well as in BCC seems to indicate that the stage of differentiation of both types of tumours is quite advanced. According to this, the main difference between the two tumours will be the malignant invasive potential of BCC. Although that might not necessarily be related to its degree of differentiation, but to changes in the phenotype of its cells with the acquisition of such an invasive potential.

\section{References}

[ 1] Kirchmann TT, Prieto VG, Smoller BR. CD34 staining pattern distinguishes basal cell carcinoma from trichoepithelioma. Arch Dermatol. 1994;130:589-592.

[ 2] Verhaegh ME, Arends JW, Majoie IM, Hoekzema R, Neumann HA. Transforming growth factor-beta and bcl-2 distribution patterns distinguish trichoepithelioma from basal cell carcinoma. Dermatol Surg. 1997;23 695-700.

[ 3] Swanson PE, Fitzpatrick MM, Ritter JH, Glusac EJ, Wick MR. Immunohistologic differential diagnosis of basal cell carcinoma, squamous cell carcinoma, and trichoepithelioma in small cutaneous biopsy specimens. J Cutan Pathol. 1998;25:153-159.

[4] Thewes M, Worret WI, Engst R, Ring J. Stromelysin-3: a potent marker for histopathologic differentiation between desmoplastic trichoepithelioma and morphealike basal cell carcinoma. Am J Dermatopathol. 1998;20:140-142.

[ 5] Kanitakis J, Bourchany D, Faure M, Claudy A. Expression of the hair stem cell-specific keratin 15 in pilar tumors of the skin. Eur J Dermatol. 1999;9:363-365.

[6] Poniecka AW, Alexis JB. An immunohistochemical study of basal cell carcinoma and trichoepithelioma. Am J Dermatopathol. 1999;21:332-336.

[7] Abesamis-Cubillan E, El-Shabrawi-Caelen L, LeBoit PE. Merkel cells and sclerosing epithelial neoplasms. Am J Dermatopathol. 2000;22:311-315.

[ 8] Naeyaert JM, Pauwels C, Geerts ML, Verplancke P. CD-34 and Ki-67 staining patterns of basaloid follicular hamartoma are different from those in fibroepithelioma of Pinkus and other variants of basal cell carcinoma. J Cutan Pathol. 2001;28:538-541.

[9] Lum CA, Binder SW. Proliferative characterization of basalcell carcinoma and trichoepithelioma in small biopsy specimens. J Cutan Pathol. 2004;31:550-554.

[10] Izikson L, Bhan A, Zembowicz A. Androgen receptor expression helps to differentiate basal cell carcinoma from benign trichoblastic tumors. Am J Dermatopathol. 2005;27:91-95.

[11] Pham TT, Selim MA, Burchette JL Jr, Madden J, Turner J, Herman C. CD10 expression in trichoepithelioma and basal cell carcinoma. J Cutan Pathol. 2006;33:123-128.

[12] Hartschuh W, Schulz T. Merkel cells are integral constituents of desmoplastic trichoepithelioma: an immunohistochemical and electron microscopic study. J Cutan Pathol. 1995;22:413-421.

[13] Hatta N, Hirano T, Kimura T, et al. Molecular diagnosis of basal cell carcinoma and other basaloid neoplasms of the skin by the quantification of Gli1 transcript levels. J Cutan Pathol. 2005;32:131-6.

[14] Narisawa Y, Hashimoto K, Nakamura Y, Kohda H. A high concentration of Merkel cells in the bulge prior to the attachment of the arrector pili muscle and the formation of the perifollicular nerve plexus in human fetal skin. Arch Dermatol Res. 1993;285:261-268.

[15] Kirkham N. Tumors and cysts of the epidermis. In: Elder DA, Elenitsas R, Johnson BL, Murphy GF, eds. Lever's histopathology of the skin. $9^{\text {th }}$ ed. Philadelphia, PA: Lippincot Williams and Wilkins; 2005:805-866.

[16] Takei Y, Fukushiro S, Ackerman AB. Criteria for histologic differentiation of desmoplastic trichoepithelioma (sclerosing epithelial hamartoma) from morphea-like basal-cell carcinoma. Am J Dermatopathol. 1985;7:207-221.

[17] Brooke JD, Fitzpatrick JE, Golitz LE. Papillary mesenchymal bodies: a histologic finding useful in differentiating trichoepitheliomas from basal cell carcinomas. J Am Acad Dermatol. 1989;21:523-528.

[18] Brenn T, McKee PH. Tumors of the hair follicle. In: McKee $\mathrm{PH}$, Calonje E, Granter SR, eds. Pathology of the skin with clinical correlations. $3^{\text {rd }}$ ed. Philadelphia, PA: Elsevier Mosby; 2005:1519-1563.

[19] Klein W, Chan E, Seykora J. Tumors of the epidermal appendages. Elder DA, Elenitsas R, Johnson BL, Murphy GF, eds. Lever's histopathology of the skin. $9^{\text {th }}$ ed. Philadelphia, PA: Lippincot Williams and Wilkins; 2005:866-926.

[20] Böer A. II. Perception visually of sections of tissue. Dermatopathology: Practical \& Conceptual 2002; 8: available at http://www.derm101.com Accesed July 7, 2007.

[21] Stanley JR, Beckwith JB, Fuller RP, Katz SI. A specific antigenic defect of the basement membrane is found in basal cell carcinoma but not in other epidermal tumors. Cancer. 1982;50:1486-1490.

[22] Votruba M, Collins CM, Harrad RA. The management of solitary trichoepithelioma versus basal cell carcinoma. Eye. 1998; 12:43-46.

[23] McKee PH. The structure and function of skin. In: McKee PH, Calonje E, Granter SR, eds. Pathology of the skin with clinical correlations. $3^{\text {rd }}$ ed. Philadelphia, PA: Elsevier Mosby; 2005:1-36.

[24] Peters EM, Botchkarev VA, Müller-Röver S, Moll I, Rice FL, Paus R. Development timing of hair follicle and dorsal skin innervation in mice. J Comp Neurol. 2002;448:28-52.

[25] Triantafyllou A, Scott J, Blacklock A. Desmoplastic trichoepithelioma of the upper lip. A case report with histochemical features and observations on its histogenesis. Oral Surg Oral Pathol Oral Radiol Endod. 1995;80:445-450.

[26] Ohnishi T, Watanabe S. Immunohistochemical analysis of cytokeratin expression in various trichogenic tumors. Am J Dermatopathol. 1999;21:337-343.

[27] Jih DM, Lyle S, Elenitsas R, Elder DE, Cotsarelis G. Cytokeratin 15 expression in trichoepitheliomas and a subset of basal cell carcinomas suggests they originate from hair follicle stem cells. J Cutan Pathol. 1999;26:113-118.

[28] Farina MC, Requena C, Requena L. Tricoblastoma. In: Requena L, ed. Neoplasias anexiales cutáneas. 1st ed. Madrid: Aula Médica; 2004:287-307.

[29] Kurokawa I, Senba Y, Nishimura K, Habe K, Hakamada A, Isoda $\mathrm{K}$, et al. Cytokeratin expression in trichilemmal carcinoma suggests differentiation towards follicular infundibulum. In Vivo. 2006;20:583-585.

Submitted: 11 October, 2007 Accepted after reviews: 20 April, 2008 